\title{
NIGERIAN VALUES AND CONTEMPORARY POPULAR MUSIC: A NEW LOOK
}

\author{
Ebele Ojukwu, Elizabeth Obielozie \& Chinyere Esimone \\ http://dx.doi.org/10.4314/0g.v12i s1.7
}

\begin{abstract}
Music is among the ancient art forms in Africa that has flourished as old as man since ancient African society did not separate their everyday activities from their music. Most music performances in Africa go beyond the frontiers of mere entertainment activity but are geared more towards socio-cultural dimensions due to its ability to socialize, consolidate values and other utilitarian exigencies. In the recent times, the younger generations of Africa seem not to have much enthusiasm for their cultural values due to undue foreign influences. Nigerian contemporary pop music is playing an increasingly pivotal role in shaping the continent's music scene. This paper seeks to portray contemporary pop music as a paradigmatic approach to enliven and perpetuate positive cultural as well as moral values in the Nigerian youths. The paper argues that contemporary Nigerian music can be employed to connect the African heritage to the world and African youths in diaspora will also have the opportunity to hear, touch, feel and create the musical art even in a distant homeland. It concludes by pointing out the need for Nigerian government to turn towards the entertainment industry and indeed the music industry with the objective of identifying possible avenues for growth in the industry, and for cultural sustainability in Nigeria.
\end{abstract}

Keywords: Nigerian values, Music industry, Contemporary popular music, Youths and society

\section{Introduction}

Before the advent of colonialism in Nigeria, the Igbo traditional community, maintain highly and uncontaminated cultural and moral values. Most of these values are taught by the elders in the people's vernacular through folktales and folk songs making it possible for the younger ones to learn early in life through songs. The above assertion no doubts collaborates Idamoyibo's view that, 'knowledge 
gained through music stays in memory for so long, till life terminates' (8). Through the folk song content, the socio cultural awareness and values are increased since it can 'capture the trust of people in a community and reach people's inner thoughts because of its popularity and cultural values' [http://heapro.oxfordjournals.org]. Also, Sreekumar opines that story tellers, singers, minstrels and other kinds of folk entertainers have acted as custodians of culture in the past. Sreekumar further highlights that the values, attitudes, beliefs and customs of the people are propagated, reinforced and perpetuated through these folk forms. Issues in a society are depicted in form of a satire by the folk artists for curing societal evils [http://sikhspectrum.com. When people exhibit certain behaviours in the past, one can easily suggest the part of culture they come from since culture is seen as the 'beliefs, way of life, art and customs that are shared and accepted by people in a particular society... activities that are related to art, music, literature, etc' (The Longman's Dictionary of Contemporary English, 382). This goes to explain why certain behaviours are attributed to certain cultures.

Nigeria's native culture by circumstances of Western civilization seems to be disintegrating and disappearing, causing a great concern. It is also being threatened today by negative cultural dynamism. In the contemporary age, this early musical exposure seems to be eluding the Nigerian youths owing to desperate quest for greener pastures in urban areas and pursuit of modernization. Ojukwu, Onuora-Oguno, \& Esimone also observe that parents hardly had time for their children and this becomes a big problem. Nigerian youths are no longer taught by the elders through folktales and folk songs of their community and the consequence of their being left unchecked is that they imbibe both the negative and positive aspects of other world cultures. The youths are most vulnerable as far as the depreciation of cultural and moral values of the nation are concerned. Presently, youths rely on social media and can spend several hours in a day on one type of social network or the other in isolation often downloading all kinds of things including all genres of contemporary music. In the light of the above therefore, this study $\mathrm{x}$-rays the efficacy of the Nigerian contemporary popular music in promoting Nigerian cultural values, job creation, mass mobilization and integration as well as national development.A brief look at the major concepts of this study is necessary at this juncture. 


\section{Value}

Value is defined as the quality or worth of a thing. It is what one considers important to him/her in life. It could be life, wealth, shelter, occupation, security, achievement, etc.Merriam -Webster's Dictionary and Thesaurus, defines value as 'something (as a principle or quality) intrinsically valuable or desirable'. Values could be beliefs or desirable goals that motivate action. It is a principle, standard or quality considered worthwhile or desirable for maintaining a set of customary standard. Values are the criteria that give meaning and significance to the total culture and society (Emeka, 16). Values are relative and require consensus among different people, they may be conceptually abstracted from the various valued items (Fitcher). This goes to explain that values guide the selection or evaluation of actions, policies, people, and events. People decide what is good or bad, justified or illegitimate, worth doing or avoiding, based on possible consequences for their cherished values. The impacts of values in everyday decisions are rarely conscious. Values enter awareness when the actions or judgments one is considering have conflicting implications for different values one cherishes. (http://www.gotquestions.org/cultural-

relativism.html\#ixzz3asl5DSx8). Every sphere in life establishes its basic values and principles that serve as the foundation for evaluation. A particular value may be very important to one person but unimportant to another. The question this study intends to seek answer to is 'What then are the criteria for evaluating or determining the 'valueableness' of Nigerian contemporary music?'

\section{Contemporary Music}

Contemporary simply put means belonging to the same time or age. The new international Webster's comprehensive Dictionary of English language defines contemporary as 'living or existing at the same time' (281). It means one of the same or nearly the same age as another. It can also mean conforming to modern or current ideas in style, fashion, design, etc. Contemporary is likely to apply to people and what relates to them, more often applied to events than to people http://www.collinsdictionary.com/dictionary/english/contemporary. Contemporary in music is a philosophical and aesthetic stance underlying the period of change and development in musical 
language that occurred around the turn of the 20th century, a period of diverse reactions in challenging and reinterpreting older categories of music, innovations that lead to new ways of organizing and approaching harmonic, melodic, sonic, and rhythmic aspects of music, and changes in aesthetic worldviews in close relation to the larger identifiable period in the arts of the time. The operative word most associated with it is "innovation" (Metzer). Its leading feature is a "linguistic plurality", which is to say that no one music genre ever assumed a dominant position (Morgan). (http://en.wikipedia.org/wiki/Modernism_\%28music\%29).

Contemporary music in Nigeria according to Lazo, 'is a brand of music that enjoys the favour of being acceptable to the people among which it is made. The acceptability can be within a given cultural or geographical location or can transcend cultural boundaries, thereby extending beyond its immediate locality'. Lazo splits Nigerian music into two groups - traditional and contemporary music. Traditional music focuses around ceremonies, celebrations, and religion as well as other parts of life. While contemporary music is centered around sharing music as entertainment purposes. (http://fsuworldmusiconline.wikidot.com/musical-history ). Within this entertainment nature of contemporary music, there are good virtues, and inherent values geared towards social goals.

\section{Popular (Pop) Music}

Popular music refers to all contemporaneous music with broad immediate and implicitly transient attractiveness which appeals to a mass audience. Such music is quite receptive to people since they are familiar with its idioms and does not require guided listening. Popular music draws its clientele from urban dwellers mostly youths being social-entertainment and dance oriented and finds its expression mostly in pubs and night clubs. Social media and other modern technologies have globalised popular music and have made it a great force of change in both social behaviour and in nation's economy (Okafor \& Okafor, 4). Popular music is a very powerful process of socio-cultural and inter cultural communication and strong source of economic growth of a nation.

The academia in the past have dismissed the socio-cultural integrity of popular music and musicians arguing that popular music is synonymous with waywardness, prostitution, illicit sex, broken 
homes and unwanted pregnancies (Ekwueme, 2004; Onyeji, 2002). On the contrary, it has been discovered through empirical studies that popular music in Nigeria is indigenous (Okafor \& Okafor, 5); Nigeria popular musicians have, at one time or the other, been invested with prestigious international and national honours in recognition of their contributions to the society as cultural ambassadors of the nation (Onwuegbuna, 155).

\section{Music Industry}

An industry consists of various specialists who make up that industry. 'Music industry involves the production, distribution and sale of music in a variety of forms as well as the promotion of life musical performance' (Miller). The industry connotes several activities and organizations by different artistes working towards specific ends but united in the common objective of processing and distributing musical product to the consumer for the purpose of making profit. The business and creative sides of the music business are inextricably linked - no matter how proficient one is creatively, he/she needs to think and operate like a business in order to remain successful. Creativity is the bedrock of every civilization and the truth of the assertion cannot be more obvious than the rapid changes that have been brought about in the wake of the internet and the digital revelation. The potentials and possibilities available and various platforms are limitless (http://www.copyright.gov.ng). Okafor opines that 'the musical industry moves a lot of money in any country' (14); even outside Nigeria. He noted that everybody that was associated with the production and marketing of music by 'the Beatles' was virtually a millionaire. Music industry is essential to the life of or existence of social life of any country. It situates at the heart of the country's entertainment industry. The industry therefore becomes a fertile ground for tapping and distributing the talents and creativity of the musicians. Music industry is the totality of the several groups involved in music production that work together towards a common objective of making money through music distribution. Okafor and Okafor early in time note that:

The system is an aggregation of several activities and organisations working towards specific ends but 
united in the common objective of distributing music for profit. As a result, the beneficiary is several centres - the composer, the artist, the industrialist, the agent, the producer, the marketer and the user. The implicated services would include advertising, banking, promotional services and public relations. The industry therefore offers opportunity for several disciplines, talents, organizations and persons. The trained or talented or qualified person can position himself in any of the strategic arms of the industry (19-20).

\section{Theoretical Framework}

The study of this nature is anchored on the theory of cultural relativism which is based on the simple fact that there are different cultures and values and each has different ways of behaving, thinking and feeling as its members learn such from the previous generation. There is an enormous amount of evidence to confirm this claim. Nketia rightly observes that the musical cultures of African societies, not only have their historical roots in the soil of Africa, but also form a network of distinct yet related traditions which overlap in certain aspects of style, practice or usage, and share common features of internal pattern, basic procedure and contextual similarities' (4). It is well known by just about every human on the planet that people do things differently around the globe. People dress differently, eat differently, speak different languages, sing different songs, have different music and dances and have many different customs. Cultural relativism is the view that all beliefs, customs, and ethics are relative to the individual within his own social context. In other words, "right" and "wrong" are culturespecific; what is considered moral in one society may be considered immoral in another, and, since no universal standard of morality exists, no one has the right to judge another society's customs. It is in that light that Okafor and Okafor aver that 'music has its cultural content and one man's sound could be another man's noise' (130). They further express that the diversity of contemporary music makes it a living theatre and consequently a part of its major strength for it always has something with which people of other cultures connect. 
Every culture of the world has their distinct norms and belief system and values but no matter the culture, there is a universally acceptable value system which 'lays strong emphasis on character and on conformity with the norms and values holding in the society' (Emeka, 294) .

\section{The Diversity of Nigerian Contemporary Pop Music Industry}

Nigerian's internal population is estimated at 200 million citizens and still growing. Nigeria is broadly conceived of in three major regions in alignment with the major ethnic groups: in the north are the Hausa, Fulani and Kanuri; in the southwest, the Yoruba and their numerous subgroups; and in the southeast, the Igbo people. This audience is enough to sustain most artistic endeavors, and most artists tailor their music to a domestic audience. Nigeria is an economic giant in Africa, with oil, industrial and trade revenues in multiples of billions. Nigerian's cultural heritage is a great source of pride, and Nigerians also have a great sense of the intrinsic wealth of their nation.

The Nigeria popular Music industry is unarguably one of the most diverse in the world. One shouldn't be surprised by the level of diversity in the industry since Nigeria in itself is a very diverse nation that houses more than 250 ethnic groups. One can hardly correctly classify any Nigerian artist as falling under a particular music genre since most artists tend to migrate rather spontaneously from one genre to another as the tides of an ever changing music culture sweeps through the country. The artists continued applying creative ideas in order to enhance their lives and explore their environment to add meaning to their life and the world at large in order not to be out of market since their propelling force is the financial gain and popularity it commands but within all these lies the message the music portrays. Buttressing the above assertion, Emeka opines, 'Every civilization in the history of mankind succeeded in applying creative ideas to enhance the life of man in its environment and to explore, explain or add meaning to the place and life of man in the cosmos' (342).

Music generally has been known to provide comfort to people in distress, as well as providing some form of entertainment. Over the centuries, Nigerian contemporary pop music has moved from one stage to another so that it can conform to the current trend. 
The industry is so dynamic that it is known worldwide. The world music isn't complete without mentioning Nigerian pop music and that is the reason different foreign artistes come to sing or perform in Nigeria. The Nigerian contemporary pop music covers so many folk songs which have their origins from the various ethnic groups in the country and popular songs with roots from other foreign cultures especially from the West. However, each kind of song is so distinctive with each having its own techniques, instruments, and language. Every performance has its targeted audience and almost all the contemporary music is targeted towards youths.

Music industry is so diverse consisting of many genres that make it a veritable avenue for molding or engineering the society's positive values especially amongst the youths since they are the driving force of any nation. The above view no doubt collaborates Okafor's assertion that, 'music is of course, very acceptable as an instrument of change because people digest it as entertainment while it leaves a mark on the psyche that re-directs the person towards a new personality, towards a new activity' (277).

\section{A Critical Look at the Nature of Nigerian Contemporary Pop Music and the Values they Portray}

In the Nigerian music industry today, values are ascribed to human beings depending on one's social status.To most artistes, the concern for values are what the plurality of people agreed upon and do not depend upon the judgment of any individual. What matters are the material gain and the social status the music accords. Udabah puts it more succinctly, "we could not speak of the values attached to behavior patterns were it not for the persons who perform these patterns. Values exist only because there are persons worthy of evaluation and competent to evaluate other persons and things' (319). One typical example of this genre migration is embodied in a particular Nigerian gospel singer turned RnB (reggae and blues) crooner who goes by the stage name, 'Flavor'. Flavor who is from the Igbo ethnic group of the predominantly Christian South-East, started out as a gospel singer, singing praise songs, but with that he did not gain much recognition. He soon found himself in the hip-hop world writing songs that could only relate to young people, lyrics that seems to be promoting or more succinctly, exalting promiscuity. No doubt this turn around accelerated his social status. This goes to 
explain that the source of values in the present day Nigeria is external to the artist since there are circumstances and conditions of value which the artist cannot control but are dependent on the manner in which the society evaluate one another and the kind of cultural object they hold in high or low esteem. Some elements of the Nigerian contemporary will be briefly discussed below.

\section{Language of Music}

The predominant language of choice in the Nigerian music industry is Pidgin English, laced with varying concentrations of pure English, and host of local languages ranging from Hausa, Igbo and Yoruba. Nevertheless, it is not uncommon to find artists that perform solely in local tongues. The rise of artists that sang hip-hop and rhythm and blues $(\mathrm{R} \& \mathrm{~B})$ in local languages couldn't have come at a better time. This is because some Nigerian languages have become threatened in recent times by Westernization and the desire to learn foreign and 'more lucrative' languages. One typical example of note is the Igbo language of Southeastern Nigeria. The Igbo language has witnessed an overwhelming decline in the number of its speakers in recent years. This can perhaps be attributed to the polarization of ideologies starting right from families where parents would prefer to communicate with their children in English rather than their local languages simply because they believe it is trendy and civilized and would thus distinguish their children from those they erroneously regard as 'the less-trained, ill-mannered, village kids'. These new generations of artists that perform in local languages have helped to bring the local languages closer to the hearts of young people; they have breathed life into them, made them likeable, even lovable. Young people can now relate in their local languages, even from other countries of the world simply because the people they admire, the people they dream about, the people they aspire to be, all sing in local languages thereby making music a powerful process of intercultural communication. Okafor and Okafor observes that 'the relationship of the language of two neighbors reflects in relationship or otherwise of their music. The closer the languages, the more similar the music, the more diverse or different the languages, the more different the music' (15).Okafor (2005) collaborates the above assertion in his remarks thus: 
Even though music and dances usually migrate through communities, as more and more people learn about them, they are cultural exports at the same time and reflect certain things about the place of origin. For that matter, the identity of the originators of the music or dance lives in fragments through other clans but is never lost entirely (87).

\section{Rhythm}

Ojukwu, Onuora-Oguno, \&Esimone summarily describe African traditional music as being characterised by its aesthetic and high rhythmic expressions. Just as European music is noted by its variety of forms and rich harmonies, Nigerian pop music is marked by the richness of its rhythms which makes it danceable. There is a connectedness between the world of any group of people and their rhythm. The predominant rhythm in the contemporary Nigerian pop music scene can be described as fast paced, usually designed to be 'danceable'. This is in line with the fact that Nigerians are a merry people and as such will usually appreciate a song based on how danceable its beats are. This ideology has given birth to a term used to refer to all songs that have rather danceable beats; party songs. One can easily guess what party songs are meant for; they are the songs that DJs (Disc Jockey) play at parties, the ones you are meant to dance to. 'Local Capability and Competitiveness of the Music Industry Exports of Music Nigeria has fashioned an African Hip Hop style of music which appeals to international audiences. A number of its musicians are internationally recognised and have received international recognition through awards such as the MTV Europe Music Award, Channel O Music awards and Kora Music awards.

\section{Lyrics}

The lyrics of any song are, of course, dependent on what the artist or singer is trying to communicate. If there were a broad classification of lyrics in the Nigerian Music Industry based on what they highlighted, then the greatest percentage would be the group songs whose lyrics 'glorify' women, their physiology and perhaps their influence on men. This would be closely followed by lyrics that talked about the hustles of life, dreams of making it big, success 
stories and all what nots. This is also in line with the fact that these songs are meant to appeal to a demographic comprising mainly of young people, who are either yet to become independent, or have just found themselves struggling to make ends meet and who certainly are fascinated by the opposite sex. The wordings of the typical Nigerian pop music is usually rendered in pidgin English, with frequent repetitions of a word or phrase typical of African music, perhaps a desperate attempt to emphasize certain words or phrase is usually found to be the title of the song.

\section{The Artists}

A closer analytical review of the music of some Nigerian contemporary pop artists reveals areas of national identity, national unity, national history, cultural globalization and national values in general. Although, there are few negative influence of the content of some Nigerian contemporary pop music that reveals a lot of vulgarity which has a consequent effect on moral decadence especially upon the youths as Adeola informs, 'artists become so carefree in their renditions and such cultures are imbibed by the Nigerian recipients of the music, thus loose and indecent language is a negative influence of popular music on the Nigerian society' (81). Adeola further highlights that many artists also believe that the use of drugs enhance their performance and some of their fans who see them as their models also indulge in the use of drugs.

These negative influences notwithstanding, a few Nigerian artists are worthy of note, some because they have pioneered a whole genre of Nigerian music and others because they have popularized and in some cases internationalized Nigeria music contributing positively towards Nigerian cultural revival, bringing it closer to Nigerians and indeed the world at large.

\section{Innocent Idibia (Tu Baba)}

Innocent Idibia (with stage name, Tu Baba, formerly known as Tuface) started his professional career with the Plantashunboyz, a trio band that consisted of him and two other artists. The band released two successful albums in 2000 and 2003 before disbanding in 2004. Tu Baba released two more albums before releasing his all time hit single, 'African queen'. He is usually credited with attracting a whole new generation of millennial to Nigerian music. He has quite 
an impressive collection of local and international music awards credited to him.

\section{Peter and Paul Okoye (P-Square)}

Peter and Paul Okoye popularly known as P-Square are Nigerian R\&B duo composed of identical twin brothers. They started out quite early, drawing inspiration from their musical Idol, Michael Jackson. Their artistic talent and precise dance routine soon made them household names in Jos, where they grew up and later became even more popular when they released their second album in 2005. Some of their albums include: 'Beautiful Onyinye', 'E no easy', etc.

\section{The Mavins}

Mavin Records is a revamped Nigerian-based record label founded by recording artist and record producer Don Jazzy on May 8, 2012. The label is home to recording artists such as Tiwa Savage, Dr SID, D' Prince, Di'Ja, Reekado Banks and Korade Bello. On May 1st, 2014, they collectively released 'Dorobucci' to critical acclaim. They have gone on to release other singles like 'Adaobi', 'LookuLooku' 'Godwin' and 'Arise'. Mavin Records was nominated for Best Record Label of the Year at the 2013 City People Entertainment Awards. The label won the aforementioned category at the 2014 City People Entertainment Awards.

\section{Wizkid}

Ayodeji Ibrahim Balogun better known by his stage name Wizkid is a Nigerian recording artist, songwriter and performer. In 2009, he signed a record deal with Banky W.'s imprint Empire Mates Entertainment. He rose to prominence in 2010 with the release of the song "Holla at Your Boy" from his debut studio album, Superstar (2011). His work and contribution to the Nigerian Music Industry has earned him several achievements, including a BET (Black Entertainment Television) award, a MOBO (Music of Black Origin) award, three times The Headiest awards, two time Channel $\mathrm{O}$ Music Video awards, four time Nigeria Entertainment awards, a Ghana Music award, two time Dynamix All Youths award, two times City People Entertainment awards, and a Future award. 


\section{Phyno}

AzubuikeChibuzo Nelson better known by his stage name Phyno, is a Nigerian rapper and record producer. He is renowned for his typical use of Igbo language in rapping. His debut studio album, No Guts No Glory, was released in 2014. It produced the singles 'Ghost Mode', 'Man of the Year', 'Parcel' and 'O Set'. Phyno is widely known as the ambassador of rap music in the Igbo Language and has been credited with attracting a whole new demographic of music lovers to the language.

\section{Conclusion and Recommendation}

The boom in Nigeria's entertainment sector and indeed the music industry couldn't have come at a better time. Oil prices are plummeting, and Nigeria being an oil export-dependent economy knows the implication of this tragedy quite well. The ripple has affected the value of the Nigerian currency against the dollar. As countries look towards non-oil sectors of their economy for growth and development, it is important that the Nigerian government turns towards popular music and indeed the music industry with the objective of identifying possible avenues for revitalization of the nation's values and growth in the industry.

It is also important that Nigerian pop musicians understand the level of participation going on in the music industry. Many Nigerian pop musicians can be said to have some kind of cult followership among fans and music lovers. This interest can be put to good use by making and passing the right messages through their music. It could come in the form of endorsements, or public awareness campaigns. A typical example is when the critically acclaimed pop musician, Innocent Idibia (Tu Baba) was used by a group of non-profit organisations to promote the 'Vote Not Fight' campaign during the run-up to the Nigerian 2015 general elections. One can easily conclude that the campaign was generally successful owing to the very minimal level of violence experienced in the 2015 general elections.

There is plenty room for growth in the Nigerian music industry. A lot of talent is still undiscovered and some have gone on to become wasted. The government can also give grants to upcoming pop musicians in a bid to commission them towards 
producing music that will promote the moral values of the country. This will in turn reduce the negative influence of the content of some Nigerian contemporary pop music that reveals a lot of vulgarity and its consequent effect on moral decadence especially on the youths.

From the foregoing discussion, attempt has been made to present the contemporary Nigerian pop music industry in the light of its cultural and moral implications geared towards nation building. Much have been revealed towards redirecting the thoughts and feelings of Nigerian populace especially the adults towards viewing the contemporary pop music from a more positive light, Though, there are few negative impacts of the industry as mentioned in the study, the positive contribution of the industry towards revitalization of the nation's values and their contributions in the nation building cannot be ignored. 


\section{References}

Adeola, T. S. "Contemporary Nigerian popular music: A tool for national development." Nigeria Theatre Journal, 6, (1). 2001: $80-85$.

Ekwume.L. E. N. Essays on African and African-American music and culture. Lagos: LENAUS, 2004

Emeka, L. N. "Traditional education in Nigeria." In Nigerian

Peoples and Culture (270 - 297). Eds. R. C Okafor and L. N.

Emeka. Enugu: New Generation Books, 2013.

Encyclopaedia Britannica Library. "Ultimate Reference Suite". $3^{\text {rd }}$

June, 2015<Merriam -Webster's Dictionary and Thesaurus>.

Fitcher, J. H. Sociology. Chicago: The University of Chicago Press, 1973.

Home - Nigerian Copyright Commission (NCC). $4^{\text {th }}$ September, $2013<$ http://www.copyright.gov.ng $>$.

Idamoyibo, I, O, "Interaction between music and culture in relation to human development in Nigeria".Nigeria Music Review, 4. Ile

- Ife: Department of Music, Obafemi University. 2003: 53 - 63.

Lazo, N. Contemporary Nigerian popular music. Available @ [https://www.unilorin.edu.ng/publications/adeolats/7.\%20Adeol a\%20Contemporary\%20Nigerian\%20Popular\%20Music.pdf] Retrieved: $5^{\text {th }}$ June, 2015.

Longman Dictionary of Contemporary English. England: Pearson Education Ltd, 2005.

Metzer, D. J. Musical Modernism at the Turn of the Twenty-first Century. New York: Cambridge University Press, 2009.

Miller, K. Music Industry Dictionary of American History. 2003. $4^{\text {th }}$ September, 2013. <http://www.wiki.encyclopedia.com>.

Morgan, Robert P. "Secret Languages: The Roots of Musical Modernism". Critical Inquiry 10, (3) (March): 442-61.1984.

Nketia, J. H. K. The music of Africa. Britain: Norton \& Company, 1982.

Ojukwu, E. V., Onuora-Oguno, N. C. \&Esimone, C. C. (2014). "The essence of introducing rhythm to the African child through folk music: A pedagogical approach". The 2014 WEI International Academic Conference Proceedings.<www.westeastinstitute.com $>$. 
Ojukwu, Obielozie \& Esimone: Nigerian Values and Contemporary Pop Music

Okafor, R. C. Music in Nigerian Society. Enugu: New Generation Books, 2005.

Okafor, R. C. \&Okafor, C. U. Music and national development in Nigeria. Enugu: New Generation Books, 2009.

Onwuegbuna, I. E. Popular music and socio-cultural integrity: The contributions of E. C. Arinze.Nsukka Journal or Musical Arts Research, 1, 2012: 154 - 162.

Onyeji, C. Popular music: Facts about the music and musicians. In E. Idolor (Ed.).Music in Africa. (pp. 24-36). Ibadan: StirlingHorden. 2002.

Oxford Journal Medicine Health Promotion International, 12 (1), 52-62. 14th April, 2013. <http://heapro.oxfordjournals.org>.

Sreekumar, C. S. Folk arts as mass communication. 2007. $14^{\text {th }}$ April, 2013. <http://sikhspectrum.com>.

The New International Webster's Comprehensive Dictionary of the English Language Encyclopedicedn. U.S.A.: Typhoon Media Corporation, 2010.

Udabah, C. "Moral obiligations to the citizen". In Nigerian Peoples and Culture (311 - 335). Eds. R. C Okafor and L. N. Emeka Enugu: New Generation Books, 2013.

What is cultural relativism? $24^{\text {th }}$ May, 2015

<http://www.gotquestions.org/cultural-relativism.html>. 